\title{
DETECTION OF WEAK D ANTIGEN IN THE POPULATION OF POTENTIAL BLOOD RECIPIENTS
}

\section{WYKRYWALNOŚĆ ANTYGENU D SŁABY W POPULACJI POTENCJALNYCH BIORCÓW}

\author{
Joanna Małgorzata Mitrus ${ }^{1(\mathrm{C}, \mathrm{D}, \mathrm{E}, \mathrm{F})}$, Urszula Adamiuk $^{2(\mathrm{~A}, \mathrm{~B}, \mathrm{~F})}$ \\ ${ }^{1}$ University of Natural Sciences and Humanities in Siedlce, Poland \\ ${ }^{2}$ Department of Transfusion Medicine, the Laboratory of Transfusion Serology at the Provincial Specialist \\ Hospital in Biała Podlaska, Poland
}

Authors' contribution Wkład autorów:

A. Study design/planning zaplanowanie badań B. Data collection/entry zebranie danych C. Data analysis/statistics dane - analiza i statystyki D. Data interpretation interpretacja danych E. Preparation of manuscript przygotowanie artykułu F. Literature analysis/search wyszukiwanie i analiza literatury G. Funds collection zebranie funduszy
Tables: 2

Figures: 4

References: 22

Submitted: 2019 Feb 28

Accepted: 2019 Jun 17

\section{Summary}

Background. The strongest immunogen of the Rh system is the D antigen. It is found in several variants and categories, which makes it difficult to determine the correct $R h D(R h+)$ or $R h D$ negative (Rh-) phenotype. Although only some of the varieties and types of this antigen are of clinical significance, it is important to determine the normal Rh phenotype in recipients and donors. The aim of this study was to determine the frequency of weak D antigen in a population of potential recipients.

Material and methods. The study group consisted of selected blood recipients in whom weak expression of the D antigen or its antibody was detected. In order to estimate the expression of antigen D, the blood was analyzed in the laboratory of the Regional Center of Blood Donation and Blood Treatment in Lublin. Blood from 220 potential recipients (149 women and 71 men) were used in the conducted research. The clinical material from the Laboratory of Transfusion Serology at the Provincial Specialist Hospital in Biała Podlaska was also used.

Results. The presence of a weak D was confirmed in 21 recipients. 4 cases of weak D were confirmed among recipients of blood transplant, while 17 cases among those who did not have blood transfusions. There were significant differences in the occurrence of the weak D in relation to the transfusion in both women $\left(\chi^{2}=18.34 \mathrm{df}=2, \mathrm{p}=0.0001\right)$ and men $\left(\chi^{2}=17.25\right)$. Conclusions. The correct determination of the RhD+ or RhD- phenotype is important for pregnant women who should be subjected to immunoprophylaxis of maternal-fetal conflict when a weak D is detected. In order to avoid post-transfusion complications among recipients, it is necessary to choose serologically and phenotypically crossed-matched blood components.

Keywords: blood, blood donor, RhD antigen, weak D, antibody

\section{Streszczenie}

Wprowadzenie. Najsilniejszym immunogenem układu Rh jest antygen D. Może on występować w kilku wariantach i odmianach, co stanowi trudność w ustaleniu prawidłowego fenotypu RhD dodatni $(\mathrm{Rh}+$ ) lub RhD ujemny (Rh-). Chociaż tylko niektóre $\mathrm{z}$ odmian i warianty tego antygenu mają znaczenie kliniczne, to jednak istotne jest oznaczenie prawidłowego fenotypu Rh u biorców i dawców. Celem pracy było określenie częstości występowania antygenu D słaby w populacji potencjalnych biorców.

Materiał i metody. Grupę badaną stanowili wyselekcjonowani biorcy krwi, u których wykryto słabą ekspresję antygenu D lub jego przeciwciała. W celu oceny wielkości ekspresji antygenu D, krew analizowano w pracowni Regionalnego Centrum Krwiodawstwa i Krwiolecznictwa w Lublinie. W przeprowadzonych badaniach przeanalizowano 220 potencjalnych biorców (149 kobiet i 71 mężczyzn). Wykorzystano też materiał kliniczny pochodzacy z laboratorium Serologii Transfuzjologicznej przy Wojewódzkim Szpitalu Specjalistycznym w Białej Podlaskiej. Wyniki. Obecność słabego antygenu D potwierdzono u 21 biorców. Biorcom, którym przetaczano krew, w 4 przypadkach potwierdzono antygen D słaby, natomiast tym, którym nie przetaczano krwi, 17 przypadków. Wykazano istotne różnice w występowaniu antygenu D słaby w zależności od transfuzji zarówno w grupie kobiet $\left(\chi^{2}=18,34 \mathrm{df}=2, \mathrm{p}=0,0001\right)$, jak i mężczyzn $\left(\chi^{2}=17,25\right)$.

Wnioski. Prawidłowe określenie fenotypu RhD+, RhD- jest istotne dla kobiet w ciąży, które w przypadku wykrycia antygenu D słaby powinny być poddawane immunoprofilaktyce konfliktu matczyno-płodowego. Chcąc uniknąć powikłań poprzetoczeniowych, biorcom należy dobierać zgodne serologicznie i fenotypowo składniki krwi.

Słowa kluczowe: krew, krwiodawca, antygen RhD, D słaby, przeciwciało 


\section{Introduction}

With exception to A and B antigens of the AB0 system, the D-antigen of the Rh system shows the highest immunogenicity of all blood group antigens and is clinically relevant. In the white population, antigen D occurs in about $85 \%$ of people. Individuals referred to as $\mathrm{RhD}$-positive ( $\mathrm{Rh}+$ ) have $\mathrm{D}$-antigen on red blood cells, while those referred to as RhD-negative ( $\mathrm{Rh}$-) do not. Both phenotypes ( $\mathrm{Rh}+$ and $\mathrm{Rh}$-) are determined by the RHD gene with variable expression. Therefore, different variants and categories of $\mathrm{D}$ antigen may be formed. The phenotypic classification may be difficult due to the existence of variants or types of the D antigen, as phenotyping only uses serological methods $[3,17]$. People with the Rh-phenotype are characterized by the complete deletion of the RHD gene. However, there are also people who have this gene or its fragments, but the expression of RHD proteins does not occur or is weakened. Then they have a "residual" presence of D antigen and describe it as "people with a weak D or D partial antigen" [5]. The reason for the weak D antigen is, among others, point mutations in the RHD gene, which cause changes in the amino acid composition of the RhD protein. The result of this mutation is the weak expression of the D antigen. Weakly expressed D antigen was also observed when the haplotype coding for the $\mathrm{D}$ antigen is in the trans position relative to the haplotype encoding the $\mathrm{C}$ antigen. Serological and genetic characteristics allowed to classify variants and weak antigen categories as partial D, weak D and DEL antigens. Weak variants of D antigen occur in about $0.2-1 \%$ of people and may stimulate the production of anti-D alloantibodies after blood transfusion in RhD negative recipients or during pregnancy in RhD negative women $[1,17]$. The clinical relevance of poor varieties is considered when a person with a $\mathrm{D}$ weak or a variant of $\mathrm{D}$ antigen after contact with RhD positive blood cells (transfusion or pregnancy) may produce anti-D antibodies, or when a negative RhD (blood recipient or pregnant woman) is exposed the risk of alloimmunization when the blood donor or fetus has a weak version of D antigen. Only some of the variants or types of D antigen are of clinical significance. Weak D and partial RhD can be the cause of immunization, therefore the determination of this antigen is very important in pregnant women and women in the premenopausal period. The generation of anti-D antibodies by them may have consequences in the course of their future pregnancies and may even cause hemolytic disease of newborns when the fetus is $\mathrm{RhD}$ positive. The poor $\mathrm{D}$ antigen determination is also important for blood recipients because they may be also prone to immunization [17].

The aim of the study was to determine the frequency of occurrence of weak D antigen in a population of potential recipients and to demonstrate its significant immunohematological significance.

\section{Material and methods}

\section{Characteristics of the study group}

The clinical material from the Laboratory of Transfusion Serology in Biała Podlaska was used for the research. Blood samples from 220 patients (149 women including 2 girls and 71 men including 1 boy) were tested. Blood group in AB0 and Rh systems, review of antibodies to red blood cells and a possible test of compliance were determined. Patients were hospitalized in various departments (surgery, internal, geriatrics, urology, neonatology, cardiology, pediatrics, OIT, orthopedics, oncology, dialysis, palliative care, gynecology, pulmonology, ENT, neurology). The average age of men was 69.5 (the youngest was a year, the oldest was $96, \mathrm{SD}=$ 19.93) and women 58.6 (the youngest was 2 years, the oldest was 100 years old, $S D=23.86$ ). The age distribution of men is consistent with the normal distribution (K-S d $=0.13 \mathrm{p}<0.20$ ), whereas in the case of women, it differed significantly from the normal distribution (K-S d $=0.14 \mathrm{p}<0.01)$. For research and statistical analysis, children were classified in the "men" and "women" groups respectively.

In order to verify the obtained results, the Kolmogorov-Smirnov test (K-S) and the $\chi^{2}$ test were used using the Statistica 12.0 software (StatSoft).

The authors have the consent of the Director of the Provincial Specialist Hospital in Biała Podlaska for the use of anonymized data.

\section{Collection and preparation of material for serological tests}

Serological tests were performed using two methods: test tube and microcolumn. From adults, 8-10 ml of venous blood were collected in a dry tube, and $3 \mathrm{ml}$ from newborns in EDTA sputum tubes (in order to take the lowest possible volume of blood to prevent anemia). The material collected in a dry tube, after previous clotting (incubation for about 1 hour at $37^{\circ} \mathrm{C}$ ), was centrifuged for 5-10 minutes at 3000 rpm to separate serum from blood cells. In contrast, blood collected on EDTA for coagulation did not require incubation and was 
centrifuged immediately after collection. Both in the serum of adults and newborns, the presence of antibodies was tested and red blood cell antigens were determined in the blood cells. The hemolyzed and lipemic samples were disqualified and the tests were performed again with newly collected blood samples, as hemolysis and significant blood lipemia could hinder agglutination and alter the results in an uncontrolled manner. The blood tubes were stored for 5 days in a cold room with temperature monitoring as recommended [11]. The collected material was used to diagnose $\mathrm{D}$ antigen from the Rh system along with its weak variants and categories. The qualification of the patient to the group of persons $\mathrm{RhD}(+)$ or $\mathrm{RhD}(-)$ was determined based on the presence or absence of D antigen on the blood cells. Specimens with dubious results for antigen D were subjected to additional testing for variants weak D and partial D. In these cases, the persons (blood recipient of the woman before the menopause) were treated as RhD negative with an unambiguous description: RhD negative "weak expression of antigen D". In order to determine in detail the weak expression of antigen D, a blood sample was transferred to the consultative office of the Regional Center for Blood Donation and Blood Treatment in Lublin. Recipients where the DVI category of the D-antigen was found or the weak D-antigen was included in the RhD negative group and negative blood was selected for transfusion. Women were included in the prevention of the Rh conflict.

The D-antigen from the Rh system was determined based on the presence or absence of agglutination of the blood cells tested with the anti-D reagent. Depending on the degree of agglutination, the RhD antigen or its variants were determined. Two monoclonal reagents were used: anti-D IgM (RUM-1) - to detect a weak type of $\mathrm{D}$ antigen (D weak) and most categories of D antigen except D VI and anti-D IgM + IgG (BLEND) - to detect a weak antigen variant D (weak D) and most categories of D antigen, including DVI. Positive control (K+) was an anti-D monoclonal reagent with $\mathrm{RhD}+$ reference cells, the negative (K-) was anti-D monoclonal reagent with RhD- reference cells.

\section{Results}

\section{Distribution of blood groups of recipients in the $A B O$ and Rh system}

Considering the presence or absence of D antigen on blood cells, recipients were divided into two groups Rh- and Rh+. We examined 125 RhD+ (57\%) - 81 women and 44 men and 95 RhD- (43\%) - 68 women and 27 men (Table 1). Analysis of the distribution of blood groups in AB0 and Rh systems revealed that the most frequent group of blood in men was ARh+ (16 people, 23\%), while the least frequent group was BRh-, which was only determined in two men (3\%). In the case of women, the most frequent group was 0Rh+ (28 people, 19\%), and the rarest was $\mathrm{ABRh}+$ and $\mathrm{ABRh}-(6$ people, $4 \%$ ) (Figure 1).

Table 1. Percentage distribution of $\mathrm{RhD}+$ and $\mathrm{RhD}$ - phenotypes

\begin{tabular}{|c|c|c|}
\hline \multirow{2}{*}{ Blood recipients } & \multicolumn{2}{|c|}{ Phenotypes } \\
\cline { 2 - 3 } & $\mathbf{R h}+$ & Rh- \\
\hline men & $44(62 \%)$ & $27(38 \%)$ \\
\hline women & $81(54 \%)$ & $68(46 \%)$ \\
\hline$\Sigma$ & $125(57 \%)$ & $95(43 \%)$ \\
\hline
\end{tabular}




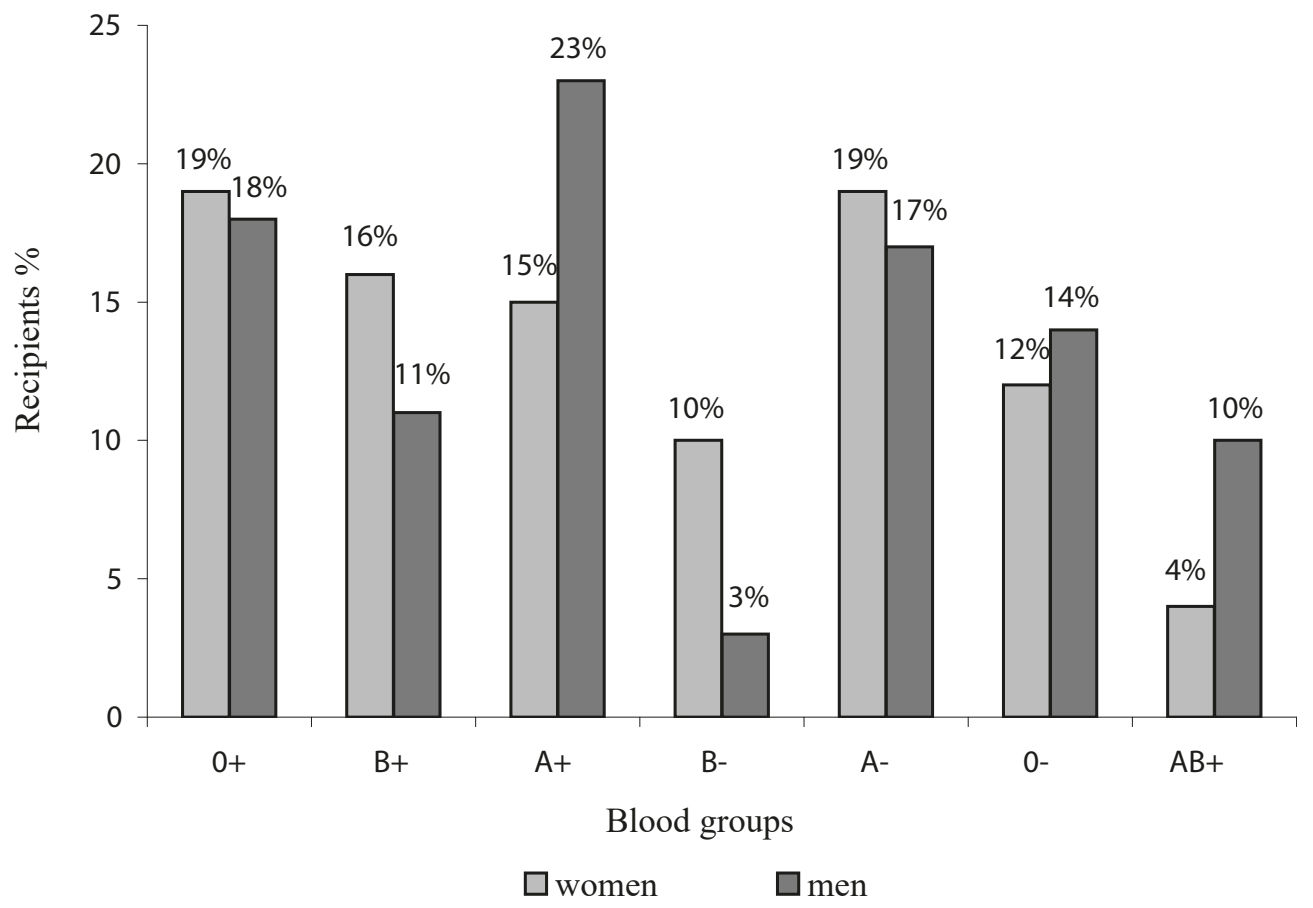

Figure 1. Percentage distribution of blood groups depending on gender

The group of blood recipients was also analyzed in the context of the phenotypes from the Rh group system occurrence. The most frequently detected phenotype in women was the dccee phenotype (41 recipients - 27.5\%) and DCcee (38 recipients - 25.5\%), and the most rarely: DCcEe and DccEE, which were found only in individual cases. Similarly, in males, the most common phenotype was dccee (14 recipients - 20\%) and DCcee (14 recipients - 20\%) (Figure 2). When comparing the phenotypes of the Rh system, there were no statistically significant differences between men and women $\left(\chi^{2}=2.57, \mathrm{df}=2, \mathrm{p}=0.28\right)$. Twenty-one recipients with weak $\mathrm{D}$ were identified. A variant with a weak D was detected in 13 women (8.7\%) and in 8 men (11.3\%) detected phenotypes of the Rh system (Figure 3).

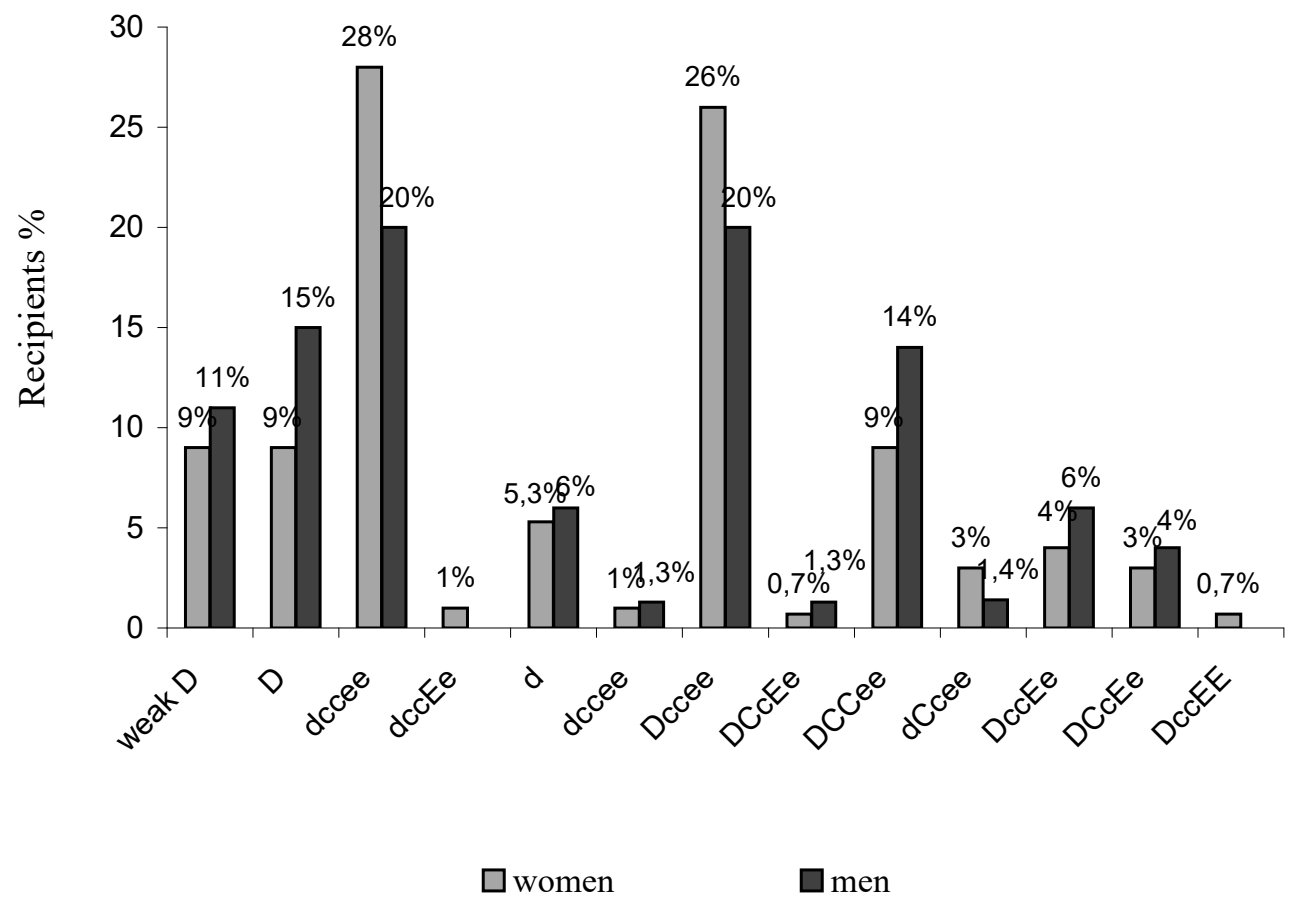

Figure 2. The role of the Rh system phenotypes depending on gender 


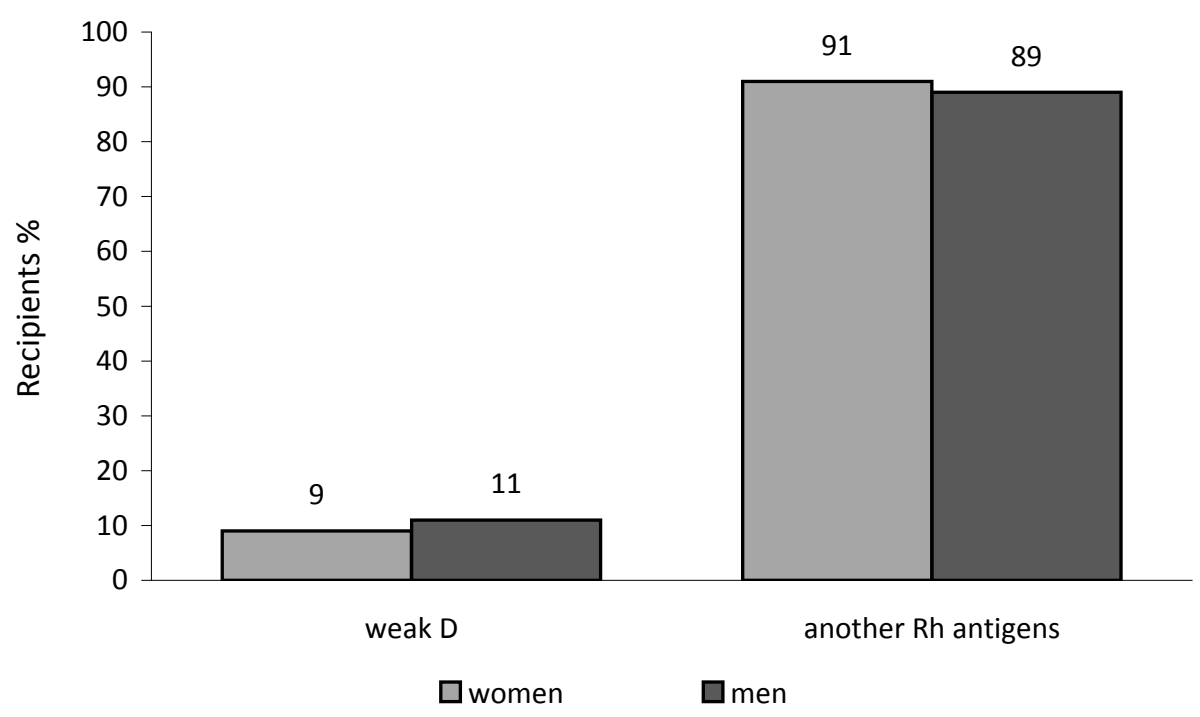

Figure 3. Percentage distribution of weak D depending on gender

\section{Weak D distribution among blood recipients}

The study group included patients hospitalized in various departments, patients from specialist clinics and individuals. Women were the most common patients in the internal ward (23\%) and gynecology and obstetrics (21\%), the least in pediatric wards, hemodialysis and palliative care (1\%). Similarly, men were most often hospitalized in the internal ward (30\%), and the least frequently in the hemodialysis wards, palliative care, pulmonology, ENT and neurology (1\%). Weak D was most often determined in cardiology patients (5 cases): 3 for women (19\%) and 2 cases for men (28\%), and the least frequently for the internal ward (two cases - 6\%).

\section{Detection of weak D in recipients treated and not treated with blood}

156 recipients had transfused blood in the study group, while 64 were not transfused. Women were the majority of recipients, 101 women were given blood (68\%) and 55 men (77\%). Among subjects who received blood transfusions, there were 4 patients with weak D (2 men - 4\% and 2 women - 2\%). In recipients who did not have blood transfusions, weak D was found in 11 women and 6 men (Table 2). The $\chi^{2}$ test compared the occurrence of the weak D depending on the transfusion. There were significant differences in both women $\left(\chi^{2}=\right.$ $18.34 \mathrm{df}=2, \mathrm{p}=0.0001)$ and in men $\left(\chi^{2}=17.25 \mathrm{df}=2, \mathrm{p}=0.001\right)$.

Table 2. The occurrence of a weak D in recipients depending on the transfusion

\begin{tabular}{|c|c|c|}
\hline \multirow{2}{*}{ Recipients } & \multicolumn{2}{|c|}{ Transfusion } \\
\cline { 2 - 3 } & Yes & 48 \\
\hline \multirow{2}{*}{ Women } & 101 & $(32 \%)$ \\
\hline \multirow{2}{*}{ Men } & $(68 \%)$ & 16 \\
& 55 & $(23 \%)$ \\
\hline \multirow{2}{*}{ Weak D Women } & $(77 \%)$ & 11 \\
\hline \multirow{2}{*}{ Weak D Men } & 2 & $(7 \%)$ \\
\hline
\end{tabular}

\section{The contribution of phenotype weak D in women depending on pregnancy}

149 women were examined, of whom 138 were pregnant. In the group of pregnant women, 11 patients (8\%) had a weak D. Women who were not pregnant constituted a minority (11 people), two of whom (18\%) were marked with a weak D antigen (Figure 4). Comparing the occurrence of weak D in women, depending on pregnancy, the $\chi^{2}$ test was performed, which did not show any significant differences $\left(\chi^{2}=3.47, \mathrm{df}=2, \mathrm{p}=0.18\right)$. 


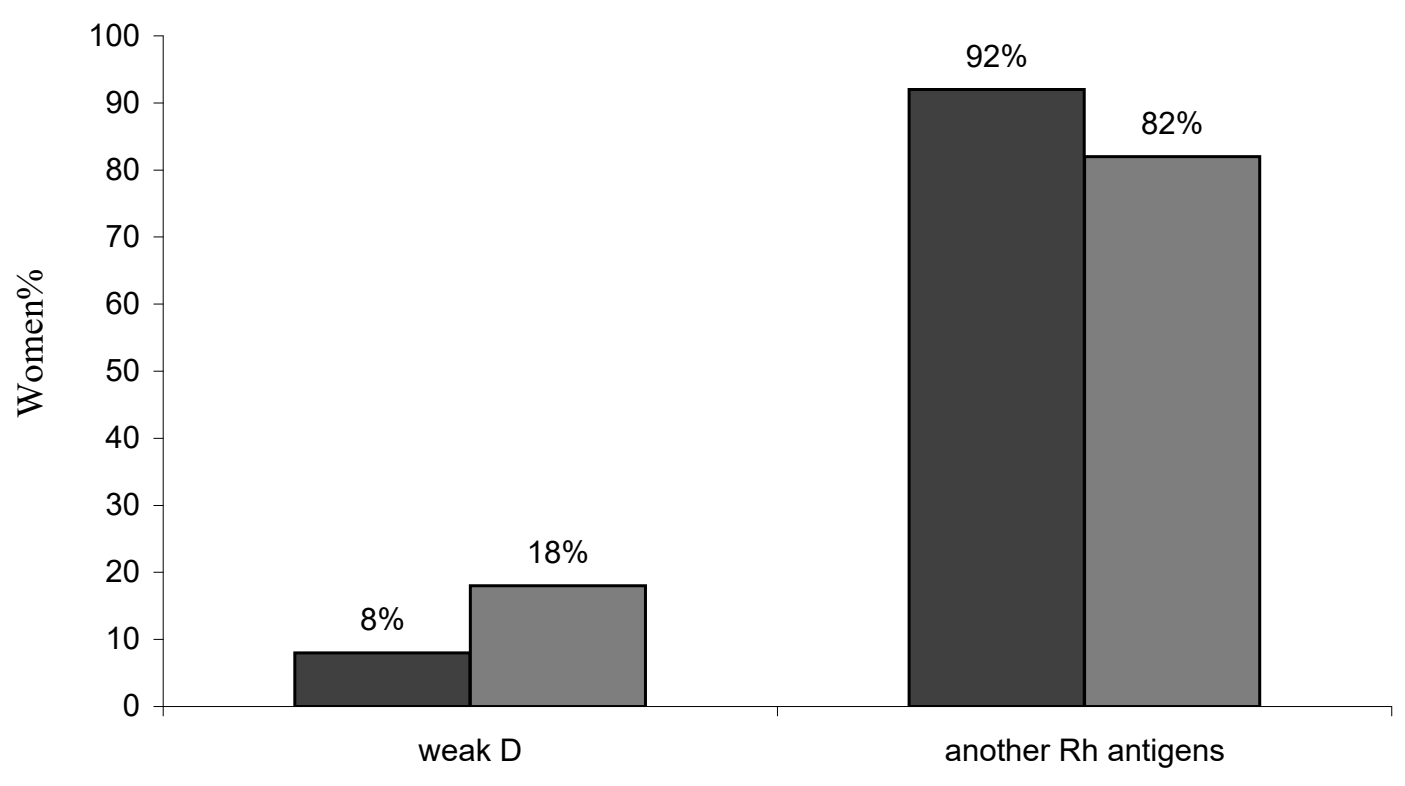

Rh antigens

$\square$ pregnant women $\square$ non-pregnant women

Figure 4. The presence of a weak D antigen in pregnant and non-pregnant women

\section{Discussion}

The D-antigen from the $\mathrm{Rh}$ system is the strongest immunogen that in over $80 \%$ of recipients stimulates the immune system to produce alloantibodies. In the human population, its presence is diverse and depends on latitude. The results of the Fabijańska-Mitek study [4] show that in the Caucasian population it ranges from 83 to $87 \%$, in Asians even over 99\%, in the black population from 82 to $95 \%$. In Poland, as many as $82.7 \%$ of people have this antigen $[1,6]$. The results of own research deviate from the literature. It was shown that $57 \%$ of the recipients tested had an Rh antigen, while $43 \%$ of the phenotypes did not have this factor. The differences may be due to the fact that in the study group there were also pregnant women RhD-, which were covered by the prevention of maternal-fetal conflict. Pregnant RhD negative increased the number of non-Rh positive recipients.

Similarly, the incidence of antigens from the AB0 system varies depending on the distribution of the geographical population. In East Asia, group B occurs two to three times more often than in Europe. The indigenous South American Indians have group 0, Australians do not have group B and AB [4]. In this study, the most frequent groups of the blood of the analyzed recipients were groups 0 and $A$, and the least frequently the group AB. This is in line with the Brojer study [3], according to which the A and 0 groups are the most common in the Polish population, and the AB group the most rarely.

In addition to the $\mathrm{D}$ antigen of the highest clinical significance, there are also other antigens in the Rh group system, such as C, E, c, e. Using specific reagents, 18 genotypic systems characteristic of this system can be detected [4]. The study analyzed the incidence of various phenotypes from the Rh system. The dccee (25\%) and DCcee (23.6\%) phenotypes were most often found in the recipient group, and DCcEe (0.7\%) and DccEE $(0.5 \%)$ were the most rarely found. According to Pelc-Kłopotowska et al. [16], in the Polish population, the dccee phenotype occurs at a frequency of 15\%. Fabijańska-Mitek [4], in her research, indicates the DCcee phenotype as the most frequent one, followed by DCcEE, dCCee and dCeEe with the lowest frequency. Own results partly agree with the literature, because a higher prevalence of the dccee phenotype has been demonstrated. This can be explained by the presence of pregnant women RhD- in the study group, which are subject to the prevention of serological conflict.

The difficulty of the correct RhD phenotype determination is the presence of its weak forms. Although only some of them are clinically relevant, this is important for recipients and donors [16]. We also analyzed the detectability of the weak D from the Rh system. 125 recipients as RhD positive and 95 RhD negative were qualified for the study. In 21 recipients very weak reactions with anti-D reagents were found, which may indicate the presence of poor expression of the D antigen. Specific serological and molecular tests confirmed 
the presence of a weak form of D antigen in all these cases (9.5\%). Generally, in the world, weak forms of D antigen (weak D, partial D and DEL) rarely occur with prevalence around 0.2-1\% [4, 15, 18]. According to PelcKłopotowska et al. [17], the percentage of people with weak D expression in Poland is $0.45 \%$. Other authors also confirm its small share in various populations, e.g. in Delhi 0.25\%, in Germany $0.21 \%$, in Austria $0.4 \%[5,8,20]$. However, own results differ from the literature. This is probably due to the fact that the study group consisted of selected recipients who were found to have a poor expression of the D antigen or its antibody. The unequivocal determination of the phenotype of these people was difficult. The recipients were subjected to further detailed serological consultations, after which their appearance was confirmed by a weak D.

Incorrect determination of a weak $\mathrm{D}$ or its types in blood donors, as well as its erroneous determination in $\mathrm{RhD}$ negative women, may lead to serious clinical consequences. As indicated by Kuśnierz-Alejska [10], in some disease, for example, myeloid leukemia or autoimmune hemolytic anemia, D antigen may be depressed. Such a case was noted in the serological laboratory of the Institute of Hematology and Transfusion in Warsaw, where in one of the patients in the acute phase of immunohemolytic anemia, the $\mathrm{D}$ antigen was periodically undetectable. The above fact shows how clinically relevant are the studies of RhD antigen expression and its correct phenotyping. Daniels [3] reports that the determination of weak D often depends on the reagents and the technique used, which is why it is very difficult to present the frequency of this phenotype. In his research, he showed that the presence of the weak $\mathrm{D}$ varies depending on the geographical location. Among donors of the white and black breed in North London, it occurs at a frequency of $0.3 \%$ to $1.7 \%$. According to Brojer et al. [2], weak D occurs in about $0.2-1 \%$ of people. Studies conducted at the Central European Blood Banks showed that 50 of the 8422 donors identified as RhD negative were found to have weak D. In Austria, 804 people were marked as RhD negative, in 18 cases fragments of the RHD gene were found. In 14 people with fragments of the RHD gene, antigen D was detected on the blood cells with reduced expression, which was not detectable in routine studies $[7,20]$.

Due to the clinical significance of $\mathrm{D}$ antigen, it is very important to determine the RhD phenotypes correctly. According to Kuśnierz-Alejska [10], transfusion of negative blood to recipients with a very poor expression of $\mathrm{D}$ antigen, classified as RhD negative, proceeds without adverse effects. On the other hand, donor blood with a low expression of $\mathrm{D}$ antigen (weak D) should not cause immunization of negative RhD recipients. Opponents of this view, however, pay attention to the possibility of clinical consequences as a result of transfusion of red blood cells with very weak D to people who produce anti-D antibodies, as well as pregnant women. Therefore, to avoid complications of potential blood donors in which weak D is present, they belong to the group RhD positive with an appropriate annotation that recipients must get RhD negative blood [11]. After analyzing our research, it was shown that in transfusion patients (156 recipients), 4 cases of weak D expression were found, while among those without blood transfusion (64 recipients) 17 cases were detected. Transfusion patients had serum-matched and phenotypically selected blood in AB0, Rh and Kell systems. According to numerous publications, RhD transfusion of the negative blood recipient to the weak D may lead to alloimmunity or other clinical complications. Therefore, the diagnostic importance of donors towards the weak $\mathrm{D}$ should be emphasized here. Brojer et al. [2] after Castilho et al (2013) describe a case of a Portuguese patient with acute myelogenous leukemia who was qualified for the RhD positive group without immune alloantibodies. The patient received $33 \mathrm{RhD}$ positive blood units within six months. Patients' anti-D antibodies were detected using specific tests in the patient's serum. It turned out that the patient was diagnosed with category DIIIc of D antigen, the detection of which is possible only through genetic tests. Pelc-Kłopotowska et al. [17], using Real-time PCR technologies (molecular studies), examined 3000 donors towards the presence of the RHD gene. Although all donors were classified as RhD negative, fragments of the RHD gene were detected in $0.45 \%$ of cases.

The diagnosis of weak $\mathrm{D}$ is also very important for pregnant women. They are exposed to alloimmunization when the fetus has a weak version of $D$ antigen. During pregnancy, women are required to perform tests both for the determination of blood group and for all erythema alloantibodies. The analysis of our results showed that among the 138 pregnant women, the weak D was detected in 11 . These women were qualified for immunoprophylaxis of maternal-fetal conflict. The results obtained are slightly different from those available in the literature. Until 2010 $428 \mathrm{RhD}$ negative pregnant women were examined in the IHiT laboratory in Warsaw, 4 of them were diagnosed with weak D, and in one of them RhDel. In the years 2000-2012, studies on the weak expression of the D. antigen were carried out in Prague. In the pool of examined people, in $827 \mathrm{RhD}$ variants were detected, 722 cases of weak D and 105 partial D $[9,18]$. Dutch scientists have analyzed the occurrence of the RHD gene in 24057 pregnant women. In 275 cases its presence was detected. In order to better diagnose the Rh serological conflict, RhD genotyping is increasingly performed in the fetus. This is a non-invasive method based on the analysis of free-running fetal DNA (cffDNA) in the mother's plasma. The priority of conducting such tests is primarily targeted at prevention of anti-D immunoglobulin only in RhD mothers, whose child has $\mathrm{RhD}+[12,18]$. 
The frequency of the weak D was also analyzed depending on the hospitalization of patients in individual wards. It was most frequent in cardiac patients. This is probably related to the high rotation of patients in this ward, and hence a large number of ordered immunohematological tests. In the internal ward, the number of patients hospitalized was the highest, however, the detectability of the weak D was the lowest. This may be due to the fact that it is a ward with chronically ill patients, the patient's turnover is very low, and therefore also the small phenotypic diversity. The discussion of these results is difficult because in the literature there are mainly data about donors, recipients, pregnant women, RhD negative, with our division based on hospitalization in different wards. It seems that the study analyzed the dependence of the occurrence of D weak in hospital wards for the first time. In the literature, generally hospitalized patients, regardless of the ward, are treated as potential recipients.

\section{Conclusions}

1. The correct determination of $\mathrm{RhD}+, \mathrm{RhD}$ - phenotypes is important for pregnant women who should be subjected to immunoprophylaxis of maternal-fetal conflict if a weak D detected.

2. Patients who were not subjected to blood transfusion were more often characterized as a weak D than in patients after transfusion.

3. In order to avoid post-transfusion complications, the recipients should be serologically and phenotypically crossed-matched blood components.

\section{References:}

1. Brojer E. [Blood group serology in practice. Training materials]. 2013 May 8-10; Warszawa (in Polish).

2. Brojer E, Guz K, Orzińska A, Pelc-Kłopotowska M, Michalewska B. [Massive molecular screening for identifying RhD negative blood donors with D weak expression]. Acta Hematologica Polonica. 2013; 44(3): 260-264 (in Polish). https://doi.org/10.1016/j.achaem.2013.07.005

3. Daniels G. Human blood group. $3^{\text {rd }}$ edition. Oxford: Wiley; 2013.

4. Fabijańska-Mitek J. [Red blood cells immunology. Blood types]. Warszawa: Oinpharma; 2007 (in Polish).

5. Flegel W, von Zabern I, Wagner F. Six years' experience performing RHD genotyping to confirm D-red blood cell units in Germany for preventing anti-D immunizations. Transfusion. 2009; 49(3): $465-471$. https://doi.org/10.1111/j.1537-2995.2008.01975.x

6. Frohn C, Dümbgen L, Brand JM, Görg S, Luhm J, Kirchner H. Probability of anti-D development in D-patients receiving D+ RBCs. Transfusion. 2003; 43(7): 893-898. https://doi.org/10.1046/j.1537-2995.2003.00394.x

7. Garratty G. Do we need to be more concerned about weak D antigens?. Transfusion. 2005; 45(10): $1547-1551$. https://doi.org/10.1111/j.1537-2995.2005.00625.x

8. Gupta A, Mirza S, Khurana S, Singh R, Chaturwedi S, Singh B. Enigmatic weak D antigen: an experience in a tertiary care hospital of East Delhi. J Clin Diagn Res. 2016; 10(6): 12-15.

9. Guz K, Orzińska A, Kopeć I, Krzemienowska M, Smolarczyk-Wodzyńska J, Brojer E. [Actual status and perspectives of the noninvasive prenatal diagnostics in feto-maternal incompatibilities]. J Transf Med. 2010; 3(4): 144-154 (in Polish).

10. Kuśnierz-Alejska G. [RhD antigen, its weak expression and categories]. Acta Haematol Pol. 2000; 31(1): 11-16 (in Polish).

11. Łętowska M. [Medical rules for blood collection, separation of its components and release, obligatory in organizational units of public blood service]. Warszawa: Instytut Hematologii i Transfuzjologii; 2014. p. 312333 (in Polish).

12. Orzińska A. [Non-invasive fetal blood group genotyping from maternal plasma]. J Transf Med. 2010; 3(4): 155-158 (in Polish).

13. Orzińska A, Guz K, Dębska M, Uhrynowska M, Celewicz Z, Wielgo M, et al. 14 years of Polish experience in non-invasive prenatal blood group diagnosis. Transfus Med Hemother. 2015; 42(6): 361-364. https://doi.org/10.1159/000440821

14. Papasawa T, Martin P, Legler TJ, Liasides M, Anastasiou G, Christofides A, et al. Prevalence of RhD status and clinical application of non-invasive prenatal determination of fetal RHD in maternal plasma: a 5 year experience in Cyprus. BMC Res Notes. 2016; 9: 198. https://doi.org/10.1186/s13104-016-2002-x

15. Pelc-Klopotowska M, Brojer E. [Selected RhD topics presented during the 23rd Regional Congress of the International Society of Blood Transfusion in Amsterdam]. J Transf Med. 2013; 6(3): 105-108 (in Polish).

16. Pelc-Kłopotowska M, Orzińska A, Michalewska B. [RhD antigen and its weak variants — serological and molecular characterization]. J Transf Med. 2012; 5(1): 25-30 (in Polish). 
17. Pelc-Kłopotowska M, Orzińska A, Michalewska B, Walaszczyk A, Gawęda J, Liszewski G, et al. [Mass screening for RHD gene fragments in RhD negative donors by minipool testing system using real-time PCR technology]. J Transf Med. 2008; 1(1): 40-45 (in Polish). https://doi.org/10.1016/j.achaem.2013.07.113

18. Pisacka M, Sklenarova M, Kralova M, Vytiskova J. D VII: the most frequent partial D in Czech population with "Hidden Iceberg" real incidence: results of a proficiency survey and D variant database in UHKT. Vox Sang. 2013; 105(1): 65-299.

19. Polin H, Denzer M, Gaszner W, Broda D, St-Louis M, Pröll J, et al. Identification of RHD alleles with the potential of ani-D immunization among seemingly D-blood donors in Upper Austria. Transfusion. 2009; 49(4): 676681. https://doi.org/10.1111/j.1537-2995.2008.02046.x

20. Polin H, Urlich S, Lanzer G. RHD*WEAK D type 48 is prevalent in Southern Austria. Vox Sang. 2013; 105(1): 65-299.

21. Veldhuisen B, Thurik F, Jonkers R. Molecular RHD variation of serological RhD negative women: implications for a fetal RHD screening programme to target anti-D prophylaxis. Vox Sang. 2013; 105(1): 1-64.

22. Wagner FF, Gassner C, Müller TH, Schönitzer D, Schunter F, Flegel WA. Molecular basis of weak D phenotypes. Blood. 1999; 93: 385-393. https://doi.org/10.1016/s0887-7963(99)80052-2 